\title{
PENGARUH PENDIDIKAN KESEHATAN PRA BEDAH TERHADAP TINGKAT KECEMASAN PASIEN PRA BEDAH DI RUMAH SAKIT DR. OEN SURAKARTA
}

\author{
Oleh : \\ Diyono $^{1}$ Budi Herminto ${ }^{2}$ Dessy Hana Pertiwi ${ }^{3}$
}

\begin{abstract}
Background. Pre-surgical patient anxiety often occur. Based on initial interviews with the majority of patients pre-surgical have anxiety with diferent level. Nursing intervention to deal the matter by providing health education although this intervention rarely give at the first day surgical period as a routine during the day prior to this it was only done as a routine and its effectiveness has not been investigated.

The purpose of the study. (1) determine the level of anxiety patient's presurgery before being given pre-surgical health education. (2) determine the level of patient anxiety pre-surgery after being given a pre-surgical health education. (3) determine the effect of pre-surgical health education to the patient's level of anxiety pre-surgery at the Hospital Dr. Oen Surakarta

Research Design. This study was a quasi-experimental study (quasi exsperiment) using all responden preoperative patients who were treated the Hospital Dr. Oen Surakarta. The sampling technique used was purposive sampling and with used Seruni and Soka Ward's Hospital Dr. Oen Surakarta. measure was a questionnaire containing 20 statements. The data collected were analyzed by paired t-dependent test used SPSS for Windows series 18 .

The results of the study. (1) the average value of patient anxiety before given health education 13.33, median 14.00, mode of 14 and a standard deviation of 2,690 . (2) the average value of the patient's pre-surgical anxiety after being given a pre-surgical health education 9,000, median 9,000, mode 9,000 and standard deviation 2,360.
\end{abstract}

Conclusion pre-surgical health education impact significantly reduce anxiety by t-test result of 0.000 .

Keywords : Health Education, Pre Surgery, Anxiety Levels

\section{LATAR BELAKANG}

Fase praoperatif merupakan saat keputusan untuk melakukan pembedahan dibuat dan berakhir ketika pasien dipindahkan ke meja operasi. Aktifitas keperawatan yang termasuk dalam fase ini antara lain mengkaji pasien, mengidentifikasi masalah keperawatan yang potensional atau aktual, merencanakan asuhan keperawatan berdasarkan kebutuhan individu, dan memberikan penyuluhan praoperatif untuk pasien dan orang terdekat pasien. (Kozier, et al., 2010)

Keputusan terapi pembedahan atau operasi merupakan sesuatu yang membuat banyak pasien merasakan takut atau cemas bahkan stres.Kondisi ini disebabkan karena pengalaman di rumah sakit sebelumnya dan disebabkan pula karena kurangnya pengetahuan tentang pra bedah. Sebagai tenaga kesehatan khususnya keperawatan berhak untuk menanyakan pada pasien tentang pengetahuan 
pembedahan sebelumnya, kondisi yang terjadi sebelum maupun sesudah pembedahan untuk menggali pengetahuan pasien. Apabila pasien mempunyai persiapan yang baik dan pengetahuan yang memadai maka perawat akan lebih mudah dalam mempersiapkan. (Potter dan Perry, 2006)

Ada bermacam-macam alasan ketakutan atau kecemasan pasien yang akan mengalami pembedahan seperti takut nyeri setelah pembedahan, menjadi buruk rupa dan tidak berfungsi normal, takut keganasan (bila diagnosis yang ditegakkan belum pasti), takut atau cemas menghadapi ruangan operasi dan peralatan pembedahan, takut mati saat dibius atau tidak sadar, takut operasi gagal. (Paramastri, 2004) Kecemasan pasien pra bedah yang tidak tertangani dengan baik dapat mengakibatkan operasi ditunda, maka sebagai tenaga kesehatan khususnya perawat dibutuhkan intervensi keperawatan yang berupa pemberian informasi atau penkes. (Potter dan Perry, 2006)

Walaupun data statistik secara pasti belum ada, masalah kecemasan pada pasien pra bedah juga banyak terjadi di Rumah Sakit Dr. Oen Surakarta. Rumah Sakit Dr. Oen Surakarta adalah salah satu rumah sakit swasta yang beralamat di Jalan Brigjen Katamso 55 Surakarta 57128. Berdasar wawancara awal dengan beberapa perawat mayoritas pasien pra bedah mengalami kecemasan dengan tingkat yang berbeda-beda.Tindakan perawat yang biasa diberikan untuk mengurangi tingkat kecemasan adalah dengan memberikan penkes atau edukasi sehari sebelum dilakukan operasi. Namun selama ini hal itu hanya dilakukan sebagai rutinitas dan efektifitasnya belum pernah diteliti secara ilmiah.
Melihat dari fenomena di atas, maka peneliti tertarik melakukan penelitian tentang "Pengaruh pemberian pendidikan kesehatan pra bedah terhadap tingkat kecemasan pasien pra bedah di Rumah Sakit Dr. Oen Surakarta".

\section{TUJUAN PENELITIAN}

Secara umum penelitian ini bertujuan untuk mengetahui pengaruh pemberian pendidikan kesehatan prabedah terhadap tingkat kecemasan pasien pra bedah di Rumah Sakit Dr. Oen Surakarta. Adapun tujuan khusus penelitian ini adalah (1) Untuk mengetahui tingkat kecemasan pada pasien pra bedah sebelum diberi pendidikan kesehatan pra bedah. (2) Untuk mengetahui tingkat kecemasan pada pasien pra bedah setelah diberi pendidikan kesehatan pra bedah.

\section{DESAIN PENELITIAN}

Penelitian ini merupakan penelitian eksperimen semu atau quasi eksperiment dengan rancangan pre post eksperimentaluntuk mengetahui pengaruh pemberian informasi pra bedah terhadap tingkat kecemasan, dengan cara membandingkan tingkat kecemasan sebelum dan sesudah diberi pendidikan kesehatan pra bedah. Quasi eksperiment adalah metode penelitian yang bertujuan untuk menjelaskan atau mengklarifikasi terjadinya sebuah hubungan dan menjelaskan hubungan sebab akibat sehingga dapat dijadikan sebagai dasar memprediksi sebuah fenomena. (Suyanto, 2011)

\section{POPULASI, SAMPEL, DAN TEKNIK SAMPLING}

Populasi merupakan seluruh subjek atau objek dengan karakteristik tertentu yang akan diteliti. Bukan hanya objek atau subjek yang dipelajari saja tetapi seluruh karakteristik atau sifat yang dimiliki subjek atau objek tertentu. (Hidayat, 
2003) Populasi yang digunakan dalam penelitian ini adalah seluruh pasien pre operasi yang dirawat di Rumah Sakit Dr. Oen Surakarta periode Januari - Februari 2014. Adapun sampel dari penelitian ini adalah 15 pasien yang dirawat di Ruang Seruni dan Soka Rumah Sakit Dr. Oen Surakarta, dengan kriteria inklusi (1) Bersedia sebagai responden, (2) Pasien Rumah Sakit Dr. Oen Surakarta, (3) Sadar penuh, (4) Tidak ada gangguan kognitif, (4) Belum pernah operasi atau operasi 1-2 kali. Teknik sampling yang digunakan dalam penelitian ini adalah teknik purposive sampling.

\section{INSTRUMEN PENELITIAN}

Pada penelitian ini peneliti menggunakan alat atau instrumen penelitian berupa kuesioner untuk mengukur tingkat kecemasan pra bedah dengan 20 pertanyaan.

\section{HASIL PENELITIAN DAN PEMBAHASAN}

Penelitian dilakukan pada tanggal 23-29 Januari 2014 bertempat di Rumah Sakit Dr. Oen Surakarta yang beralamat di Jalan Brigjen Katamso 55 Surakarta 57128. Data diambil dengan cara mengukur tingkat kecemasan pasien sebelum dilakukan pembedahan, kemudian diberikan pendidikan kesehatan pra bedah dan setelah selesai diukur kembali tingkat kecemasan pasien. Selama melakukan penelitian peneliti menemui beberapa hambatan diantaranya hambatan waktu, pengambilan data dilakukan pada saat proses renovasi pembangunan rumah sakit sehingga situasi lingkungan penelitian kurang kondusif. Karena berlangsungnya proses pembangunan maka yang seharusnya sampel 3 bangsal hanya dilakukan menjadi 2 bangsal yaitu Soka dan Seruni.

\section{Hasil Penelitian}

1. Karakteristik Responden berdasarkan Umur Karakterisitik responden berdasarkan umur terlihat pada tabel 4.1 .

Tabel 4.1. Distribusi Frekuensi Responden Berdasarkan Umur

\begin{tabular}{ccc}
\hline Umur & $\mathrm{f}$ & $\%$ \\
\hline $15-30$ & 6 & 40 \\
$31-46$ & 4 & 26.67 \\
$47-62$ & 1 & 6.67 \\
$63-78$ & 3 & 20 \\
$79-94$ & 1 & 6.66 \\
\hline Jumlah & 15 & 100 \\
\hline
\end{tabular}

Dari tabel di atas diperoleh informasi bahwa sebagian besar responden berjumlah 6 responden (40\%) berada pada kelompok umur 15-30 tahun dan jumlah responden paling sedikit 1 responden (6.67\%) berada pada kelompok umur 47-62 tahun dan 1 responden $(6.67 \%)$ berada pada kelompok umur 79-94 tahun.

2. Karakterisitik Responden Berdasarkan Jenis Kelamin

Tabel 4.2. Distribusi Frekuensi Responden Berdasarkan Jenis Kelamin

\begin{tabular}{ccc}
\hline Jenis Kelamin & $\mathrm{f}$ & $\%$ \\
\hline Laki-laki & 11 & 73.33 \\
Perempuan & 4 & 26.67 \\
\hline Jumlah & 15 & 100 \\
\hline
\end{tabular}

Tabel di atas terlihat responden yang berjenis kelamin laki-laki berjumlah 11 responden (73.33\%), responden yang berjenis kelamin perempuan berjumlah 4 responden (26.67\%). 
3. Kecemasan sebelum diberi pendidikan kesehatan

Tabel 4.3.Distribusi Frekuensi Tingkat Kecemasan Pasien Pra Bedah Rumah Sakit Dr. Oen Surakarta sebelum diberi Penkes

\begin{tabular}{ccc}
\hline Nilai & $\mathrm{F}$ & $\%$ \\
\hline $0-5$ & - & - \\
$6-10$ & 3 & 20.01 \\
$11-15$ & 9 & 60 \\
$16-20$ & 3 & 19.99 \\
\hline Jumlah & 15 & 100 \\
\hline
\end{tabular}

Dari tabel di atas ditemukan bahwa skor atau nilai kecemasan pada 0-5 tidak ada, nilai kecemasan 6-10 sebanyak 3 responden $(20.01 \%)$, nilai kecemasan terbanyak pada nilai kecemasan 11-15 dengan 9 responden $(60 \%)$ dan nilai kecemasan pada 16-20 sebanyak 3 responden (19.99\%).

Hasil Analisa Univariat Hasil analisa univariat adalah seperti tabel 4.4. di bawah ini :

Tabel 4.4. Hasil Analisa Univariat nilai Kecemasan

\begin{tabular}{ll}
\hline Komponen & Hasil \\
\hline Mean & 13.33 \\
Median & 14.00 \\
Modus & 14 \\
Standar Deviasi & 2.690 \\
\hline
\end{tabular}

Dari tabel di atas menunjukkan bahwa mean (rata-rata) pada nilai kecemasan pasien pra bedah sebesar 13.33, sedangkan median (nilai tengah) sebesar 14.00 dan modus (nilai yang sering muncul) adalah 14 dan standar deviasi sebesar 2.690 .
4. Kecemasan setelah diberi pendidikan kesehatan

Distribusi frekuensi tingkat kecemasan pasien pra bedah

Tabel 4.5. Distribusi Frekuensi Tingkat Kecemasan Pasien Pra Bedah Rumah Sakit Dr. Oen Surakarta sesudah diberi penkes

\begin{tabular}{ccc}
\hline Nilai & $f$ & $\%$ \\
\hline $0-5$ & 1 & 6.67 \\
$6-10$ & 10 & 66.66 \\
$11-15$ & 4 & 26.67 \\
$16-20$ & - & - \\
\hline Jumlah & 15 & 100 \\
\hline
\end{tabular}

Dari tabel di atas ditemukan bahwa kecemasan terbanyak pada nilai 6-10 yaitu 10 responden $(66.66 \%)$, nilai kecemasan pada 11-15 sebanyak 4 responden $(26.67 \%)$ dan nilai kecemasan pada 16-20 tidak ada.

Hasil Analisa Univariat Hasil analisa univariat menunjukkan mean 9,00, median 9,00, modus 10, dan std 2,360. Secara lebih rinci adalah seperti pada tabel 4.6 di bawah ini:

Tabel 4.6. Hasil Analisa Univariat Nilai Kecemasan Paska Pemberian Penkes

\begin{tabular}{ll} 
Komponen & Hasil \\
Mean & 9.00 \\
Median & 9.00 \\
Modus & 10 \\
Standar Deviasi & 2.360 \\
\hline
\end{tabular}


5. Pengaruh pendidikan kesehatan pra bedah terhadap tingkat kecemasan pasien pra bedah

Tabel 4.7.Pengaruh Pendidikan Kesehtan Pra Bedah Terhadap Tingkat Kecemasan Pasien Pra bedah di Rumah Sakit Dr. Oen Surakarta

\begin{tabular}{|c|c|c|c|}
\hline \multirow{2}{*}{ Nilai } & \multicolumn{2}{|c|}{$\begin{array}{c}\text { Hasil analisa } \\
\text { univariat }\end{array}$} & \multirow{2}{*}{$\begin{array}{c}\mathrm{T}- \\
\text { test } 2\end{array}$} \\
\cline { 2 - 3 } & Pre & Post & tailed \\
\hline mean & 13.33 & 9.00 & \\
\hline Median & 14.00 & 9.00 & 0.000 \\
\hline modus & 14 & 10 & \\
\hline
\end{tabular}

Berdasarkan tabel di atas memperlihatkan penurunan nilai kecemasan mean sebelum diberi pendidikan kesehatan 13.33, median 14.00 , modus 14 dan mean sesudah diberi pendidikan kesehatan 9.00, median 9.00, modus 10. Hasil T-test 2 tailed 0.000 , kurang dari 0,05 yang menunjukkan bahwa ada pengaruh pemberian pendidikan kesehatan pra bedah terhadap tingkat kecemasan pasien pra bedah dibuktikan dengan terjadi penurunan nilai kecemasan pasien pra bedah.

\section{PEMBAHASAN}

1. Kecemasan sebelum diberi pendidikan kesehatan

Frekwensi nilai kecemasan pada pasien pra bedah paling banyak adalah pada rentang nilai 11-15 yaitu 9 responden (60\%). Nilai tersebut membuktikan bahwa kecemasan pasien pra bedah sebelum diberi pendidikan kesehatan tentang pembedahan masih tinggi.
Menurut Suliswati, et al. (2005) kecemasan merupakan respon individu terhadap suatu keadaan yang tidak menyenangkan dan dialami oleh semua makhluk hidup dalam kehidupan seharihari. Pengertian lain dari kecemasan menurut Bandiyah dan Lukluk (2011) kecemasan yaitu ketegangan yang tinggal secara samar-samar karena merasa takut pada hampir sebagian besar waktunya dan cenderung beraksi secara berlebihan terhadap stres yang ringan sekalipun. Hasil analisa univariat juga membuktikan bahwa kecemasan pasien pra bedah sebelum diberi pendidikan kesehatan masih tinggi, dimana nilai rata-rata adalah 13, median 14, dan modus pada nilai 14 .

Hal ini sesuai dengan pendapat Wilkinson dan Nancy, (2011) dimana kecemasan terjadi pula pada pasien pra bedah dengan tingkatan tertentu ringan, sedang, maupun berat. Gejala klinis kecemasan dapat berupa frekuensi berkemih meningkat, merasakan jantung deg-degan tidak seperti biasa, merasakan pusing. Dari observasi yang peneliti lakukan pada pasien pra bedah juga merasakan hal ini yang disebabkan karena mereka merasa takut dan kurangnya pengetahuan tentang operasi yang akan dilakukan di ruang operasi.

2. Kecemasan setelah diberi pendidikan kesehatan

Berdasarkan tabel 4.7 frekuensi tingkat kecemasan pasien pra bedah di Rumah Sakit Dr. Oen Surakarta terbanyak pada nilai 6-10 yaitu 10 responden (66.66\%), hal ini membuktikan bahwa nilai kecemasan pasien pra bedah setelah diberi 


pendidikan kesehatan
menunjukkan penurunan.
Pendidikan kesehatan dapat
menambah wawasan dan
informasi mengenai apa dan
bagaimana proses pembedahan
yang akan dialami sehingga
pasien merasa lebih tenang dan
siap untuk menjalani operasi
atau pembedahan. Hal ini juga
ditunjukkan dengan penurunan
nilai rata-rata kecemasan
menjadi 9,00 .

3. Pengaruh Pendidikan Kesehatan Pra Bedah terhadap Tingkat Kecemasan Pasien Pra Bedah

Berdasarkan tabel 4.7 terlihat terdapat penurunan nilai mean sebelum diberi pendidikan kesehatan 13.33 menurun menjadi 9.00 setelah diberi pendidikan kesehatan. Hasil paired T-test dengan program SPSS versi 18.0 menunjukkan adalah sebesar $0.000(<0,05)$ sehingga hipotesa diterima, atau dapat diambil kesimpulan ada pengaruh pemberian pendidikan kesehatan pra bedah terhadap tingkat kecemasan pasien pra bedah pada pasien pra bedah di Rumah Sakit Dr. Oen Surakarta.

Menurut Adnani (2011), pendidikan kesehatan adalah melakukan intervensi atau perlakuan terhadap faktor perilaku pendidikan kesehatan, sehingga perilaku individu sesuai nilai-nilai kesehatan. Pengertian lain pendidikan kesehatan menurut Notoatmojo (2011), adalah suatu proses untuk mencapai perubahan perilaku masyarakat ditekankan pada faktor predisposisi perilaku, dengan pemberian informasi atau peningkatan pengetahuan dan sikap.
Menurut Notoatmodjo (2011), tujuan diberikan pendidikan kesehatan antara lain mengubah pengetahuan atau pengertian, pendapat, dan konsep-konsep, mengubah sikap dan persepsi, menanamkan tingkah laku atau kebiasaan yang baru.

Berdasarkan hasil dari analisa univariat juga menunjukkan bahwa sebelum diberi pendidikan kesehatan pra bedah mean adalah 13.33, median 14.00, modus 14 dan nilai rata-rata setelah diberi pendidikan kesehatan pra bedah menurun menjadi 9.00 , median 9.00 dan modus 10 , menunjukkan bahwa nilai kecemasan sebelum dan sesudah ada perubahan atau terjadi penurunan nilai kecemasan dengan adanya hasil univariat.

Hasil penelitian ini hampir sama dengan penelitian terdahulu yang dilakukan oleh Sarwitri (2011). Penelitian tersebut berjudul Pengaruh Pemberian Informasi Terhadap Kecemasan di Bangsal Ortopedi RSUI Kustati Surakarta. Bertujuan untuk mengetahui pengaruh pemberian informasi pra bedah terhadap tingkat penurunan kecemasan pasien sebelum operasi. Rancangan berupa pre test - post test desain, dengan subjek penelitian 58 responden. Teknik sampel dengan metode quota sampling, sedangkan metode pengumpulan data menggunakan kuesioner Hamilton Ratting Scale for Anxiety. Teknik analisis data menggunakan t-tes. Hasil penelitian menunjukkan bahwa ada perbedaan tingkat kecemasan pada pasien, sebelum dan sesudah 
pemberian informasi pra bedah di ruang Ortopedi RSUI Kustati Surakarta. Dengan tingkat signifikansi $5 \%$ dan derajat bebas 57 , menunjukkan hasil $\mathrm{t}$ hitung (7.366) >t tabel (2.002).

Penelitian lain yang relevan dengan penelitian ini adalah penelitian menurut Maria (2012) penelitian yang berjudul pengaruh tingkat kecemasan pada pasien pre operasi dengan general anestesi sebelum dan sesudah diberikan relaksasi otot progresif di Rumah Sakit Panti Wilasa Citarum Semarang. Desain penelitian menggunakan Quasi eksperimental, dengan rancangan berupa one group pre test - post test desain, dengan subjek penelitian 30 responden. Uji statistik menggunakan paired sample ttest. Hasil penelitian menunjukkan terdapat perbedaan yang signifikan antara tingkat kecemasan sebelum dan sesudah diberikan relaksasi otot progresif dengan $p(0,000)$ atau $<0,05$.

Sesuai bahasan di atas dapat disimpulkan bahwa pemberian pendidikan kesehatan pra bedah mempengaruhi penurunan kecemasan pada pasien pra bedah sebelum dilakukan operasi yaitu ada pengaruh dapat menurunkan kecemasan pasien pra bedah.

\section{PENUTUP}

A. Kesimpulan

1. Nilai rata-rata kecemasan pasien pra bedah sebelum diberi pendidikan kesehatan pra bedah adalah 13.33, median 14.00, modus 14 dan standar deviasi 2.690.

2. Nilai rata-rata kecemasan pasien pra bedah sesudah diberi pendidikan kesehatan pra bedah turun menjadi 9.000 ,median 9.000, modus 10 dan standar deviasi 2.360 .

3. Pendidikan kesehatan pra bedah berpengaruh secara signifikan menurunkan kecemasan dengan hasil $t-$ test 0,000 .

B. Saran

1. Pendidikan kesehatan pra bedah sebaiknya dijadikan sebagai prosedur tetap (protap) rumah sakit dalam melakukan perawatan pasien yang akan menjalani operasi.

2. Sebaiknya instansi pendidikan keperawatan meningkatkan frekwensi dan kwalitas pemberian materi pendidikan kesehatan pada pasien pra bedah .

\section{DAFTAR PUSTAKA}

Adnani, Hariza. Ilmu Kesehatan Masyarakat. Yogyakarta : Nuha Medika, 2011.

Suliswati, et al. Konsep Dasar Keperawatan Kesehatan. Jakarta : EGC, 2011.

Bandiyah, Siti dan Lukluk Zuyina. Psikologi Kesehatan. Yogyakarta : Nuha Medika, 2011.

Hawari, Dadang. Manajemen Stres, Cemas, dan Depresi. Jakarta : FKUI, 2011.

Fitriani, Sinta. Promosi Kesehatan. Yogyakarta : Graha IImu, 2011.

Kozier, Barbara, et al. Fundamental Keperawatan Konsep, Proses dan Praktik. Edisi 7.Volume 2. Alih bahasa Esty 
Wahyuningsih, et al. Jakarta : EGC, 2010..

Potter, Patricia A dan Anne G. Perry. Buku Ajar Fundamental Keperawatan Konsep, Proses dan Praktik. Edisi 4.Volume 2. Alih bahasa Renata Kumalasari, et al. Jakarta : EGC, 2006.

Notoatmodjo, Soekidjo. Kesehatan Masyarakat IImu dan Seni. Jakarta : Rineka Cipta, 2011.

Hidayat, A. Aziz Alimul. Metode Penelitian Keperawatan dan Teknik Analisis Data.Jakarta : Salemba Medika, 2009.

Fajar, Amin et al. Statistika untuk Praktisi Kesehatan. Yogyakarta : Graha IImu, 2009.

$\begin{array}{crr}\text { Sarwitri. Pengaruh } & \text { Pemberian } \\ \text { Informasi } & \text { terhadap } \\ \text { Kecemasan } & \text { di } & \text { Bangsal } \\ \text { Ortopedi } & \text { RSUI } & \text { Kustati } \\ \text { Surakarta. } & \text { URL } & \text { : }\end{array}$

http//jurnal.pdi.lipi.go.id/ admin/jurnal/11081318.2011.

Wilkinson, Judith M., Ahern dan Nancy R. Buku Saku Diagnosis Keperawatan. Edisi IX. Alih bahasa Esty Wahyuningsih, et al. Jakarta : EGC, 2011.

Suyanto.Metodologi dan Aplikasi Penelitian Keperawatan. Yogyakarta : Nuha Medika, 2011.

Riwidikdo, Handoko. Statistik Kesehatan Belajar Mudah Teknik Analisis Data Dalam Penelitian Kesehatan.Yogyakarta : Mitra Cendikia Press, 2009.

1 Dosen AKPER Panti Kosala Surakarta

2 Dosen AKPER Panti Kosala Surakarta

3 Mahasiswa AKPER Panti Kosala Surakarta 